Portland State University

PDXScholar

5-8-1996

\title{
The Reception Theory of Hans Robert Jauss: Theory and Application
}

Paul Hunter Rockhill

Portland State University

Follow this and additional works at: https://pdxscholar.library.pdx.edu/open_access_etds

Part of the History Commons

Let us know how access to this document benefits you.

\section{Recommended Citation}

Rockhill, Paul Hunter, "The Reception Theory of Hans Robert Jauss: Theory and Application" (1996). Dissertations and Theses. Paper 5153.

https://doi.org/10.15760/etd.7029

This Thesis is brought to you for free and open access. It has been accepted for inclusion in Dissertations and Theses by an authorized administrator of PDXScholar. Please contact us if we can make this document more accessible: pdxscholar@pdx.edu. 


\section{THESIS APPROVAL}

The abstract and thesis of Paul Hunter Rockhill for the Master of Arts in History were presented May 8, 1996, and accepted by the thesis committee and the department.

COMMITTEE APPROVAJS:

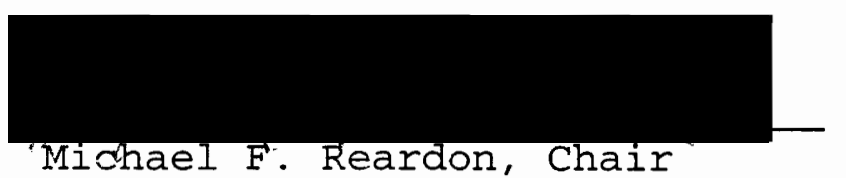

DEPARTMENT APPROVAL:

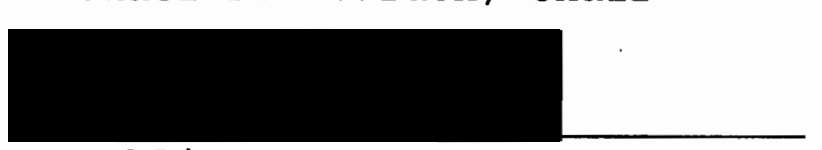

Franklin C. West

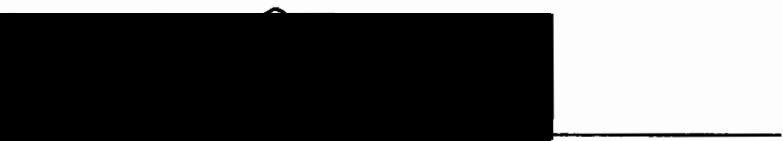

Steven N. Fuller

Representative of the office of Graduate Studies

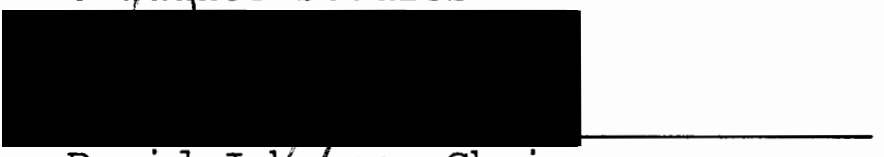

David Jolngson, Chair

Department of History

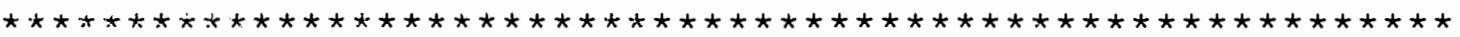

ACCEPTED FOR PORTLAND STATE UNIVERSITY BY THE LIBRARY
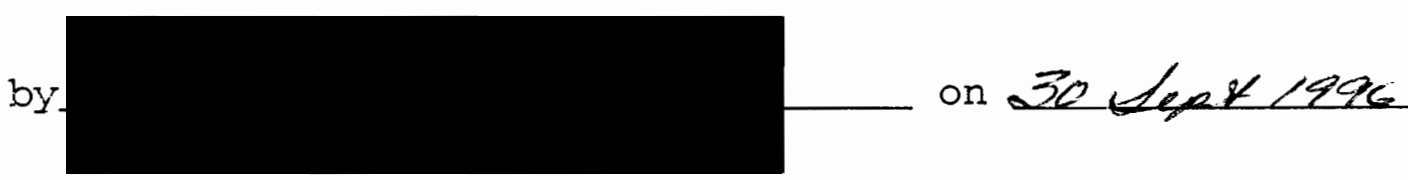


\section{ABSTRACT}

An abstract of the thesis of Paul Hunter Rockhill for the Master of Arts in History presented May 8, 1996.

Title: The Reception Theory of Hans Robert Jauss: Theory and Application.

Hans Robert Jauss is a professor of literary criticism and romance philology at the University of Constance in Germany. Jauss co-founded the University of Constance and the Constance group of literary studies.

Hans Robert Jauss's version of reception theory was introduced in the late 1960s, a period of social, political, and intellectual instability in west Germany. Jauss's reception theory focused on the reader rather than the author or text. The original reception of a text was compared to a later reception, revealing different 
literary receptions and their evolution. Jauss's Rezeptionsgeschichte (history of reception) illustrated the evolution of the reception of texts and the evolving paradigms of literary criticism that they were a part of. However, Jauss's essays proved to be more of a provocation for change in literary criticism than the foundation for the next literary paradigm. The empirical studies discussed in this thesis reveal the idealism of Jauss's theory by testing main ideas and concepts. The results show the inapplicability of Jauss's theory for practical purposes.

The intent of this study is to illustrate the origins, development and impact of Jauss's version of reception theory. The interrelationship between the social environment, the institutional reforms at the University of Constance, and the methodology of reception theory are also discussed.

The new social values in west Germany advocated individualism and questioned status quo institutions and their authority. This facilitated the establishment of the University of Constance, which served as the prototype for 
the democratization of German universities and the introduction of Jauss's reception theory. With the democratization of the university, old autonomous faculties were broken down into interdisciplinary subject areas. The old Philology and New Philology department were made into the sciences of language and literature and ultimately introduced as the all-encompassing Iiteraturwissenschaft. Five professors from the Slavic, English, German, Classics and Romance language departments gave up direction of these large departments to work together under the Constance reforms in an effort to form a new concept of literary studies. The result was the socalled theories of "reception" and "effect" which they continue to research. 
THE RECEPTION THEORY OF HANS ROBERT JAUSS:

THEORY AND APPLICATION

by

PAUL HUNTER ROCKHILL

A thesis submitted in partial fulfillment of the requirements for the degree of

MASTER OF ARTS

in

HISTORY

Portland State University

1996 


\section{ACKNOWLEDGEMENTS}

Research conducted in Freiburg was made possible by a Laurels scholarship and the History department at Portland State University. Many thanks go to Dr. Michael F. Reardon of Portland state University and helpful staff members of the Freiburgische Universitätsbibliothek. 
TABLE OF CONTENTS

PAGE

ACKNOWLEDGEMENTS . . . . . . . . . . . .

CHAPTER

INTRODUCTION. .................. 2

I THEORETICAL ANTEDEDENTS OF RECEPTION THEORY 4

Russian Formalism............ 5

Prague structuralism........... 11

Hans Georg Gadamer.............. 15

II INSTITUTIONAL REFORMS AT THE UNIVERSITY OF

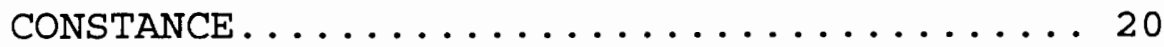

III ORIGINS OF HANS ROBERT JAUSS'S RECEPTION THEORY...................... 29

IV METHODOLOGICAL DEVELOPMENT OF JAUSS'S THEORY IN REGARDS TO THE CLASSICS........ 55

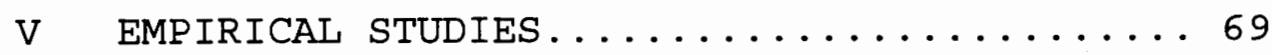

Eggert, Rutschky and Berg's study.... 71

Hillman's study............. 74

Vaget's study................ 79

VI CONCLUSION..................... 83 


\section{INTRODUCTION}

Hans Robert Jauss is a professor of literary criticism and romance philology at the University of Constance in West Germany. Jauss is a co-founder of the University of Constance and a member of the Constance group of literary studies so named because members have taught or do teach at the southern German university. The Constance school is an association of scholars with common methodological concerns. Jauss is also the founder and coeditor of Poetik and Hermeneutic. He has taught at Columbia, Yale and the Sorbonne. His writings include studies of Medieval and modern French literature as well as theoretical works. Although his works have received little attention in the United States, the University of Minnesota Press has published two volumes of his work: Toward an Aesthetic of Reception and Aesthetic Experience and Iiterary Hermeneutic. Against this backdrop, Hans 
Robert Jauss introduced his reception theory, which led to institutional and methodological reforms.

This thesis illustrates the theoretical antecedents, theory, and application of Hans Robert Jauss's reception theory. The sociology of knowledge approach discusses the social environment during the late 1960 s in West Germany and the institutional reforms at the University of Constance that contributed to the positive reception of Jauss's theory.

Jauss's version of reception theory focused attention on the reader at the expense of author and text. Concentrating on the reader, Jauss attempted to reconstruct the reception of a text at a specific time or over a certain time period. Past receptions of texts are compared to present receptions, enabling us to find out how the original reader understood the work, by recognizing the "hermeneutic difference" between past and present understanding. Jauss referred to the latter as the history of reception (Rezeptiongeschichte). The establishment of a history of reception was one of Jauss's main goals. 
In this thesis Chapter one outlines the intellectual antecedents that contributed to the development of Jauss's reception theory. Chapter Two reveals the institutional reforms introduced by Jauss and his colleagues at the University of Constance and their relationship to the positive reception of reception theory. Chapter Three provides an introduction to Jauss's major essays and main theoretical concepts. Chapter Four chronicles Jauss's theoretical relationship to the classical genre over the course of three essays, illustrating the evolution of his theory. Chapter Five analyzes empirical studies in their attempt to apply the major concepts of Jauss's theory. 
CHAPTER I

THEORETICAL ANTECEDENTS OF RECEPTION THEORY

Identifying the precursors of reception theory can be done without much effort. The label of antecedents in this chapter applies to the theories that appeared during the 1960s and that outlined an intellectual climate in which reception theory could prosper. 1 Three influences have been identified on this basis: Russian Formalism, Prague structuralism, and Hans Georg Gadamer's hermeneutics. These three have had an obvious impact on theoretical developments illustrated in the footnotes or sources of reception theorists, or because they have contributed to the solution in the crisis of literary scholarship in refocusing attention on the text-reader relationship. 2

This work is not a comprehensive analysis of the intellectual precursors that contributed to the

1Robert C. Holub, Reception Theory: A Critical Introduction (New York: Metheun, 1984) 14.

${ }^{2}$ Holub 14. 
development of reception theory, nevertheless an attempt must be made to identify some of the contributors to the theoretical developments which influenced the Constance School. In addition, the theories cannot be treated in their entirety. Each theory includes extensive and complex views of literature and art that are not addressed in this chapter. The areas discussed are limited to those aspects relevant to reception theory. What is represented are the theories that dominated the literary scene in West Germany in the late 1960s and early 1970s.

\section{RUSSIAN FORMALISM}

Russian formalism has been most often associated with structuralism or new criticism, but its contribution to reception theory is significant. Reception theory in the 1970s had a different focus and perspective of Russian formalism than the structuralism movement; the focus was no longer on the autonomous work or its linguistic roots. Reception theorists were interested in the text-reader relationship: "By widening the concept of form to include 
aesthetic experience, by defining the work of art as the sum of its devices, and by directing attention to the process of interpretation itself, the Russian formalists contributed to a novel manner of exegesis closely related to reception theory."3 In regard to literary history, of primary significance for reception theorists was the formalist concept of the evolution of literary schools, depicting a process of competing schools struggling for hegemony .

The writings of Russian formalist Viktor Shklovskii depict the shift in emphasis from the relationship between author and work to the relationship between text and reader. Imagery is not the main element of literature since it is simply a means of creating the strongest possible impression, one of many poetic "devices" used to maximize effect. According to Shklovskii, while examining art, one should begin with basic laws of perception, not with symbols or metaphors, and in this field Shklovskii discovers the guiding principles for analyzing works of

$3_{\text {Holub } 16 .}$ 
art. 4 Shklovskii states that ordinary perception has a tendency to become automated, which ultimately leads to the failure to see the particular object, instead merely recognizing it, resulting in perception in habitual form. The true function of art, however, is to deautomatize perception. Consequently, the reader's role is of primary importance as ultimately it is the reader who determines the artistic quality of the work: "The artistry attributed to the poetry of a given object is the result of our perception; artistic objects, in the narrow sense, are those that are created with special 'devices', whose purpose is that these objects, with the greatest possible certainty, be perceived as artistic." 5 According to this theory, only objects that are perceived as artistic and that deviate from habitual perception can be defined as "artistic"; thus the fundamental element of art becomes perception and reception. 6

$4_{\text {Holub } 16 .}$

5 Texte der Russischen Formalisten eds Jurij Streidter and Wolf-Dieter Stempel, (München: Fink, 1969, 1972) qtd. in Holub, 17. 
Applying this approach, developed by the early formalists, it becomes evident why the "device" became a major tool in literary interpretation: the "device" is the means by which we become aware of objects and the techniques which make the things perceivable as artistic. ${ }^{7}$ The "device" in Russian formalism, although used for different purposes by different theorists, shares three characteristics: First, the "device" is always defined as a primary element used in constructing the work of art; second, it functions against a specific background, whether practical language or literary tradition; third, and of prime importance, the device is the element that connects the text and the reader, thus making the work an authentic aesthetic object. 8 Shklovskii's concept of defamiliarization is, however, most often associated with the "device." Ostranenie (making strange) describes a certain relationship between reader and text that withdraws the object from its normal perceptive field,

\footnotetext{
$6_{\text {Holub } 17 .}$

$7_{\text {Holub } 17 .}$

$8_{\text {Holub } 18 .}$
} 
making it a constitutive element of all art: "The device of art is the device of defamiliarization of objects and the device of the form made difficult, a "device" that increases the difficulty and length of perception, for the process of perception is in art, an end in itself and must be prolonged."9 Defamiliarization, according to Shklovskii, serves two purposes: first, the "device" reveals linguistic and social conventions, coercing the recipient to see a work in a new and more critical light. Conversely, the "device" draws attention to form itself, compelling the reader to disregard social factors by focusing on the process of defamiliarization as a element of art. Critical here is the formulation of a basic concept of the reading process.

In addition to the formalist's former contributions to reception theory, they have also aided reception theorists in the area of literary history. Formalist theory states that progression in art can be viewed as the application of the concept of "device." "Since 'device' is

9streider and stempel 14-15 qtd. in Holub, 18. 
defined by shklovskii in terms of its ability to defamiliarize perceptions and since what is familiar is determined to some extent by current literary practices, changes in art are brought about by a rejection of the contemporary artistic modes. The end result is successive generations of literary schools which constantly evolve by replacing old techniques with formal innovations."10 According to Shklovskii, literary history does "progress", but not in a straight line. "The new hegemony is usually not a pure instance of restoration of earlier form, but one involving the presence of features from other junior schools, even features inherited from its predecessors on the throne."II The leading group of elements that dominate literature over a given time period are referred to as dominants. According to Shklovskii, literary history is the constant replacement of one group of dominants by

$10_{\text {Holub } 21 .}$

$11_{\text {Boris }}$ M. Eikenbaum, "The Theory of the Formal Method," Reading in Russian Peetics (Cambridge, Mass: MIT Press 1971) 32 . 
another. They do not totally disappear but temporarily recede only to resurface again in another context.

\section{PRAGUE STRUCTURALISM}

Similar to the Russian formalists, Jan Mukarovsky and the Prague structuralists received very little attention from the English speaking world. However, the writings of Mukarovsky played a major role in the late 1960 s and the 1970s in Germany. Mukarovsky was an advocate of the Russian formalist school, but his popularity in Germany was due to his focus on specific receptionoriented aspects of Russian formalism. Up until 1930 Mukarovsky was an avid supporter of the principles of Russian formalism, condemning analysis that went beyond the boundaries of the autonomous text. However, by the mid 1930s Mukarovsky began to question the adequacy of Russian formalist theory.12 In an 1934 essay on Shklovskii's Theory of Prose, Mukarovsky cautiously objects to some 
theoretical points of his formalist predecessors but salvages some of Shklovskii's theoretical concepts, concluding that they were never formalist to begin with. By identifying the artwork as a semantic composition and by uniting form and content, Shklovskii had taken the first steps towards clarifying the semiotic value of art. Mukarovsky identifies the interpretation of social reality and the literary text as the centerpiece of Shklovskii's theory. 13

Mukarovsky's concept of art as a signifying system in which art works are individual structures that refer to their predecessors is important for reception theorists, since this illustrates that structures are not independent of history nor are there limitations of size and scope. According to Mukarovsky, "the individual work is only one example of a structure; potentially, any author's oeuvre, contemporary art forms, or even national or international literature can be studied structurally as well."14

13 Burbank and Steiner 16 qtd. in Holub 31.

14 Burbank and Steiner 16 qtd. in Holub 31. 
Important for reception theorists is these structures act as signs. Mukarovsky identifies a work of art itself as a "semiotic fact" that mediates between the artist and the listener or reader. Mukarovsky's semiotic perspective refuted psychological criticisms such as Geistesgeschichte as well as criticisms that treat art as a reflection of social reality. The way is then clear for Mukarovsky to concentrate on aesthetic response and the semiotic character of the works of art, which according to Mukarovsky serves two functions: same as a communicative sign and that of an autonomous structure. The communicative function is compared to parole(the actual manifestation of speech in a given language). 15 The autonomous structure is divided into four parts: "A work, thing, or artifact; the sensory symbol that corresponds to the signifier; 'an aesthetic object,' lodged in the social consciousness and functioning as meaning or signified." And finally the referential aspect of the sign or the relation to the thing signified.16

$15_{\text {Holub } 31 .}$ 
According to Mukarovsky, the reader is neither an autonomous idealized individual nor an abstract phenomenological subject, but a product of his or her social relations, emphasizing the collective process in the reception of art.17 In his 1936 essay "Aesthetic Function, Norm and Value of Social Facts,"18 the work of art is described as a social sign and its viewer "a social creature, a member of a collective."19 Artistic norms play a major role in the movement towards a sociologically influenced aesthetics of reception. Mukarovsky insists that a norm cannot be separated from the sociological aspect: "The approach to the problem of the aesthetic norm through sociology is not only a possible approach, or simply an ancillary one, but is, together with the poetic

$16_{\text {Burbank }}$ and Steiner 88.

17 Holub 32.

$18 \mathrm{Jan}$ Mukarovsky, Aesthetic Function, Norm and Value as Social Facts, trans. Mark E. Suino. (Ann Arbor: University of Michigan Press, 1970).

${ }^{19}$ Holub 32. 
aspect of the problem, a basic requirement for research." 20

Mukarovsky also identifies the importance of social classes and aesthetic social relations in the establishment and changing of norms. Contrary to the formalists, Mukarovsky does not concentrate solely on avant-garde art, but conversely, documents the infiltration of avant-garde art into the various social strata of society. Mukarovsky's two most important realizations about artistic norms are that they "are not static, eternal constructs, and that the coexistence of several different and even conflicting norms is a commonplace occurrence." 21

HANS GEORG GADAMER

The ideas of Hans Georg Gadamer have been very influential in dealing with the situated nature of our

$20_{\text {Holub } 33 .}$

$21_{\text {Holub }} 33$. 
interpretations and the historical nature of our understanding, but his influence in the development of reception theory is somewhat misleading. 22 In his best known work, Iruth and Method, Gadamer attempts to discredit what many reception theorists sought: a method for studying and analyzing literature and a method for arriving at the truth about the text.23 The "and" in Truth and Method is analyzed in its disjunctive sense, and Gadamer's main target in support of this theory is the methodology of the natural sciences, although Gadamer's attack on method could be applied to the debate that has taken place within reception theory.

Method, according to Gadamer, is something applied to an object to achieve a certain result. The methods of the natural sciences have falsely been associated with truth. Gadamer consequently defines the objective of Truth and Method as follows: "It aims to seek out the experience of truth that transcends the realm of control of scientific

$22 \mathrm{Holub} 33$.

$23_{\text {Holub } 35 .}$ 
methodology wherever it is met, and to inquire into the legitimacy proper to it." 24 Gadamer proposes hermeneutics, the science of understanding and interpretation, as the corrective device to overcome the failures of all methodological endeavor and attempts to clarify understanding (verstehen) as such, not in correlation to a specific discipline, but conceived as the essence of our being in the world.25 Therefore Gadamer's hermeneutics goes against the fundamental idea of reception theory which, according to Jauss, attempts to objectively analyze a literary text. However, Jauss does borrow some of Gadamer's key concepts. Gadamer's terms "effective history" (Wirkungsgeschichte), along with "horizon" comprise the two main theoretical contributions for reception theorists. Wirkungsgeschichte, Gadamer claims, is the reality of history in that it is the history of realization: What is real works--that is, in realizing

24 Hans Georg Gadamer, Truth and Method, trans. Garrett Barden and John Cummings (New York: Continuum, 1975) xii.

$25_{\text {Holub } 39 .}$ 
itself it works itself out. Wirkungsgeschichte is not enough to explain the understanding of tradition in which we do not take part. Thus there must also be a wirkungsgeschichtliches Bewusstsein (effective-historical consciousness) that recognizes what is occurring when encountering the past. 26

The situation of understanding is our "horizon." "Horizon" is our situatedness, and marks the limit of everything that can be seen from a particular point of view; it is not a closed perspective, rather, "something into which we move and that moves with us." 27 "Horizon" also is defined by the multitude of prejudices we take with us at any given time. The act of understanding is therefore described as a fusion of "horizons" (Horizontschmelzung):

Though there can be and often are two different horizons, one of the historian and the other of the tradition he wants to understand, this does not mean that they are, or should be, alienated from each other. It does not mean that the historian needs to place himself in the other horizon in any other sense

$26_{\text {Holub }} 40$.

$27_{\text {Holub } 42 .}$ 
than that he needs to place himself in it--that is, try to understand what the other is saying as true. And the truth always means what is true from the historian's viewpoint within his own horizon, as well as within the others. 28

Dispite Gadamer's methodological disclaimers, his philosophical hermeneutics has been fertile ground for Hans Robert Jauss and reception theory, including concepts such as "effective-history," "horizon" and "wider hori-nn of experience of life." But no matter how important terms such as the "horizon of expectations,"

(Erwartungshorizont) and "effective-history" have become for reception theorists in their analysis of literary texts, they go against Gadamer's original philosophical intentions because they use the concepts but not the original meaning. 
CHAPTER II

INSTITUTIONAL REFORMS

The preceding intellectual movements received interest from reception theorists during the social and political instability of the 1960 s in west Germany which provided the backdrop for the founding of the University of Constance and the Constance school in 1966 . Constance was used as a experimental platform for the introduction of institutional reforms in order to facilitate the restructuring of German universities. The three main pillars of reform were: the democratization of the university as an institution; the restructuring of an education in the historical disciplines into the training for a profession; and the revision of scholarly and theoretical understanding. 29

29 Hans Robert Jauss, Hermann Nesselhauf, Gebremste Reform. Ein Kapitel deutscher Hochschulgeschichte: Universität Konstanz 1966-76, (Konstanz: Universitätsverlag, 1977) vorwort xii. 
Jauss played a major role in the implementation of institutional reforms at the University of Constance. In Gebremste Reform: ein Kapitel deutscher

Hochschulgeschichte: 1966-1976 Jauss contributes an essay on the educational reforms at the University of Constance from the years 1969-1972. Jauss begins by discussing the contributions of the Humboldt model of reform and concludes that "their requirements were elitist, without consideration for practical occupational training." These included priority of the monologue method in the Vorlesung, seminars with research but without group work, and autonomy of professors over course offerings (with no control by department). In addition, there was no structured academic plan and no standardized examinations.30 The price, according to Jauss, was that students, enforceable in the growth period of the 1950s, were neither prepared vocationally for employment nor academically for research assignments. This was not the result of anonymous students in an overcrowded

30 Jauss, Nesselhauf, Gebremste 64. 
environment, this was a result of professors being loaded down with increased administrative duties in addition to job security almost wholly dependent on publishing.31

What was the objective of the Constance reform movement? In the initial report of the Grundungsausschuss [founders' committee] in 1965, reforms were proposed based on Humboldt's idea that, "teaching should be based on the progress made in research,"32 and this was the impetus for the first generation of reforms at the University of Constance. The departments were given the responsibility for teaching and research, as well as the implementation of new academic policies. The committee's initial attempts at pedagogical reforms ultimately failed, and this led to the formation of the Ausschusses für Lehrfragen [ALF, the committee for pedagogical inquiries]. Jauss, being its first appointed chairman, proceeded with a report of the reform attempts made by this committee. Jauss claims its task was to: first, convert the old department autonomy

31Jauss, Nesselhauf, Gebremste 64.

32Jauss, Nesselhauf, Gebremste 63. 
into a cooperative structure of "subject areas" [Fachbereiche]; second, to develop new forms of cooperative work and independent control through interdisciplinary committees for research, teaching and examinations; third, these committees were to initiate modern pedagogical reforms such as smaller study groups, interdisciplinary work in research and teaching, and finally, to implement a series of reformed teaching models.33 For example, a central committee was responsible for the restructuring of the sequence of examinations from Zwischenprufung to Habilitation.

Two additional sub-committees playing important roles in establishing initial reforms were the Ausschuss für Nachwuchsforschung(committee for next generation research) and the Ausschuss für Forschungsfragen (committee for research questions) which assigned departments the introduction and revision of teaching methods in conjunction with research, restructured on the principles of interdisciplinary associations, cooperation and self-

33 Jauss, Nesselhauf, Gebremste 65. 
regulation. Also the task of developing an employmentoriented study plan was put in the hand of the teachers and students.

According to Jauss, parity existed in ALF horizontally among the 15 departments, as well as vertically between teachers and students. This contrat social functioned under the motto "consensus through selfdetermination."34 The student assistants as well as the rest of the student body played an equal role from the beginning in the establishment and make-up of all the committees. ALF created an interdisciplinary and intercooperative representation through a rolling membership whose members were chosen by junior faculty and students.35 However, leftist movements, Jauss notes, within the student body saw the reforms only as a pretext for the implementation of their own critical reforms based on the ideals of anti-authority and condemnation of a meritocracy.

34Jauss, Nesselhauf, Gebremste 66.

35Jauss, Nesselhauf, Gebremste 67. 
The protocol of the first ALF meeting on April 18, 1969, focused on three issues:

Studienorganization: Agreement of standardization of testing methods, optimal structuring of the academic calendar and public access to exams.

Studienordnung: Establishment of requirements for vocational oriented studies, interdisciplinary selection of pedagogical models, and the establishment of new academic departments.

Hochschuldidaktik: Standardization of grading policies, researching the effectiveness of newly implemented academic reforms on target groups, and the establishment of entrance quotas.36

Jauss states that pressure for quick solutions forced ALF to concentrate on the formation of committees which focused on the restructuring of academic requirements. This was done at the expense of pedagogical reforms, which could have utilized the methodological developments of previous foreign and domestic university experiences in

36Jauss, Nesselhauf, Gebremste 67. 
educational instructional reforms. Consequently Jauss identifies the three major results of ALF: the restructuring of examination regulations, the introduction of new academic departments, and an agreement to attempt to reform academic organizations.37

of the Constance reforms, the restructuring of departments proved most successful in the revision of the classical subject divisions in favor of interdisciplinary connections. For example, the conventional old and New Philology departments were made into the sciences of language and literature, and ultimately introduced as the all-encompassing literarturwissenschaft which was later adopted nationally.38 Five professors from each of the existing faculties, English, German, Classics, Romance languages, and Slavic languages gave up the direction of these large departments to work together under the Constance reforms. The five professors formed a interdisciplinary group and pursued the opportunity to

37Jauss, Nesselhauf, Gebremste 68.

38 Jauss, Nesselhauf, Gebremste 68. 
form a new concept of literary studies. "This concept aimed at converting the methods of national philologys into the new, interdisciplinary unity of literary studies which was to be grounded in the general development of theory, and thus not merely in the comparative consideration of literature."39 The development of theory demanded an opening up of philological/historical praxis to scientific requirements, something which new movements abroad had already paradigmatically accepted but which were lacking in West Germany."40 In carrying out this methodological prescription, Jauss and other Constance literary critics have from the beginning developed a particular concept, the so-called theories of "reception" and "effect", which they continued to research. This resulted in a concept of communications science that is based on close collaboration with such neighboring disciplines as text linguistics, sociology and philosophical hermeneutics. The following chapter

39Rien T. Segers, "An Interview with Hans Robert Jauss," New Literary History 11 no. 1 (1979) 92.

40 Segers 92 . 
discusses the origins and development of Jauss's contributions to this movement. 
CHAPTER III

ORIGINS OF HANS ROBERT JAUSS'S RECEPTION THEORY

The political, social and intellectual environment of West Germany in the late 1960s provided fertile ground for the founding of the University of Constance in 1966 and the introduction of reception theory. Jauss used the new department of Literaturwissenschaft to introduce his methodological reforms in the study of literature to a intellectual community adamantly questioning status quo methods of interpretation. Jauss's major essays responsible for the introduction of reception theory were "Paradigmawechsel in der Literaturwissenschaft," and "Literary History as a Challenge to Literary theory." In the former essay Jauss outlines the paradigmatic evolution of literary history from Classical-humanism to Historicalpositivism to the latest paradigm Aesthetic-formalism reaching the conclusion that the third paradigm has been exhausted thus opening up the door for the introduction of a fourth paradigm. Jauss outlines the necessary 
requirements for the fourth paradigm, combining contributions from the two possible candidates structuralism and Marxism, which Jauss ultimately disqualifies. Next the influence reception theory had on German literary theory along with a brief attempt at explaining factors contributing to this phenomenon is shown. Finally, Jauss's major theoretical essay is discussed identifying his major concepts and goals in the seven theses in his essay.

Jauss attempts to pinpoint the nature of the revolution then taking place in the study of literature in his 1969 essay, "Paradigmawechsel in der Literaturwissenschaft." The representation of the history of the natural sciences as the history of paradigmatic change goes back to Thomas $S$. Kuhn in Die struktur der wissenschaftlichen Revolution. 41 According to Kuhn, scientific paradigms exist for a certain time period as recognized scientific solutions that are replaced by a new system when they no longer provide suitable interpretation

$41_{\text {Thomas }} \mathrm{S}$. Kuhn, Die Struktur der wissenschaftlichen Revolution (Frankfurt: Suhrkamp, 1967). 
for advanced research. Jauss applies Kuhn's theory to literary investigations since the given paradigm determines the method of interpretation as well as the objects of interpretation-but in an ongoing process. A paradigm is disregarded when it no longer fulfills the requirements presented by literary studies and a new and more qualified paradigm, independent of the older model, replaces the obsolete approach, until it is unable to fulfill its function of explaining past works of literature for the present.

Jauss then outlines the previous paradigmatic evolution in literary history beginning with the "classical-humanist" paradigm. The major intellectual movement influencing the development of scholarship in Germany during the last three decades of the 18 th century was Neuhumanismus: "The use of the language, literature and other cultural artifacts of past cultures, especially that of Greece, for the development of the analytic and creative powers of modern individuals and cultures, originating as a new literary and historical 
conception."42 This was achieved through study and appreciation of Greek language, literature and art. Greek authors became models of style and expression. The literary critic was required to measure present works against the fixed rules of the classics in order to determine whether they satisfied their literary codes and conventions. 43

The second paradigm was the "historical/positivistic" paradigm which began in the early 19th century. The historicity of the epochs, styles, authors and works was used as the framework, and the classical canon of the authors of antiquity faced competition from a more modern canon. The new paradigm was that of historical explanation. The literary work was described based on the coordinates of time, space and environment. The literary traditions provided the idea of the individual identity of the nation and its unique literary tradition. "German

42 Carl Diehl, Americans and German Scholarship 17701870, (New Haven and London: Yale University Press, 1978) 11 .

43 Diehl 11. 
historiography of this period was based on the character of political power, and concentrated on the conflict of the great powers while neglecting social and economic history." 44 German historicism was permeated with political ideas, including the German literary revival of the 18th century, which involved an attempt to free national literature from the influence of French neoclassical patterns; more important, German political nationalism arose in the struggle against French domination of Germany in the aftermath of the wars of the French revolution and Napoleonic victories, a struggle which intensified the anti-Enlightenment bias of German political thought. 45 The activities of scholars in this paradigm focus on source studies and the editing of critical studies in the national tradition. Jauss cites the beginning of the First World War as the end of

44George G. Iggers, The German Conception of History: The National Traditional of Historical Thought from Herder to the Present (Middletown, Conn.: Wesleyan University Press; Scranton Pa: Harper and Row, 1983) 7.

45 Iggers 9 . 
widespread application of "historicist-positivist" application. 46

The third paradigm, "aesthetic-formalism," arose in the early 2oth century and developed out of the growing discontent with the "positivist" approach which attempted to explain the literary work as the sum total of its historical conditions. "The basis of this (aesthetic formalism) method is characterized by the premise that a historical explanation is less effective than analyzing the work itself as a system of language, style and composition. Structuralism contributed to this movement by practicing closed readings which focused on the establishment of a "scientific method" as the basis of literary theory."47 Geistesgeschichte, Russian formalism, and New Criticism all represent the third paradigm, as they all transfer the focus from historical explanations to concentration on the text itself. 48

46Hans Robert Jauss, "Paradigmawechsel in der Literaturwissenschaft," Linguistische Berichte 3, (1969) 49.

47Jauss, "Paradigmawechsel" 49. 
Jauss recognized the exhaustion of the "aestheticformalist" paradigm starting with W.W.II and he identifies the revitalization of philosophical hermeneutics and the demand for more socially relevant criticism as signs of dissatisfaction with the third paradigm. Unable to determine precisely the fourth paradigm and its methodology, Jauss delineates specific qualifications it must fulfill. The fourth paradigm, Jauss confirms, is responsible for the interpretation, mediation, and actualization of past art: "This specific accomplishment of a literary paradigm is the ability to wrest works of art from the past by means of new interpretations, to translate them into a new present, to make the experiences preserved in past art accessible again, or, in other words, to ask the questions that are posed anew by every generation and to which the art of the past is able to speak and again to give us answers."49 More specifically, Jauss outlines three specific methodological requirements

48 Holub 4. 49 Jauss qtd. in Holub 4. 
for a fourth paradigm, taking into account the complications of a contemporary society:

1) The mediation of aesthetic/formalist and historical/reception related analysis, as well as art, history and social reality;

2) The linking of structural and hermeneutic methods;

3) The probing of an aesthetics (no longer related solely to description) of effect (Wirkung) and a new rhetoric, which can equally well account for "high-class" literature as well as popular literature and phenomena of the mass media. 50

Jauss claimed that incremental progress had been made towards this paradigm at the University of Constance. 51

50Jauss, "Paradigmawechse1" 56.

51Jauss, "Paradigmawechsel" 46. 
The reason behind the present situation is said to be the lack of a guiding principle which provides a link between past and present. Jauss depicts how Marxism and Structuralism attempted and failed to solve this problem that eliminated them as potential candidates for the fourth paradigm. Marxism is dismissed since it is considered to consist only of mechanistic procedures and consequently identified with the "historicist-positivist" movement. Structuralism is discredited because it has not shown the unity required for paradigmatic status. Reception theory seems to be the only possible paradigm able to satisfy the criteria that Jauss postulates, although Jauss never confirms reception theory as actually being the fourth paradigm. 52

How could reception theory, almost unknown in 1965, become so popular over the next decade? In this regard the discussions of how paradigms change in literary

52 Jauss, "Paradigmawechsel" 46. 
scholarship is interesting because potentially it entails the appearance of reception theory itself. Regardless of whether one thinks of it as a change of paradigm or a shift in emphasis no one can question the enormous impact that reception theory has had on the interpretation of literature and art.

The extent of reception theory's influence can be exemplified in two examples. In 1977 a bibliography could cite more than 400 entries related to reception theory in Günther Grimm's Rezeptionsgeschichte; and in 1972 the conference of German teachers in stuttgart devoted two entire sections to the examination of reception theory development. 53

In 1979, The Ninth Congress of the International Comparative Literature Association was introduced under the title "Literary Communication and Reception;" the results were published the following year in a 436 page volume. 54 Applications to the literary canon have been

53 Holub 7 .

54 Holub 8 . 
just as prevalent. In one way or another reception theory has been used to discuss French Troubadour lyrics, the English Novel, the Nouveau Roman, and works in the German tradition from the Niebelungenlied to Günther Grass's Local Anesthetics. From Marx to formalism, from classical scholars and medievalists to modernists, "virtually every methodological direction and area of literature has been challenged by reception theory."55

Why did these responses occur? As stated in Chapter I the dynamic social, political and intellectual environment provided a ideal background for the introduction of a new literary theory that questioned prevailing methods of criticism. This was revealed intellectually, as a crisis developed in literary studies in the fields of German language and Iiterature, through Germanistik students' dissatisfaction with the inability of the neutral scholarly practices to confront new problems and scholarly questions.56 Young academics then sought alternatives for

55Robert C. Holub, "Trends in Literary Theory: The American Reception of Reception Theory," The German Quarterly, 55 (1982) 81 . 
future investigations. One of the most influential documents of this crisis, Views of a Future Germanistik (1969)57, identifies German studies as a troubled discipline in need of reform, and proposes sweeping changes for academic programs. The sequel to this volume New Views of a Future Germanistik (1973) 58 reveals more about the direction of literary studies. The first section of contributions is grouped under the heading, "Problems of a Social and Reception History of Literature" which identified the influence of reception theory in the restructuring of literary studies in West Germany. 59

Against this backdrop, Hans Robert Jauss introduced the theoretical framework of reception theory. Jauss's most influential essay, "Literary History as a Challenge to Literary Theory" questions the prevailing methodologies

56 Reese 27.

57Jürgen Kolbe, (ed.), Ansichten einer Künftigen Germanistik, (München: Hanser, 1969).

58 Jürgen Kolbe, (ed.), Neue Ansichten einer Künftigen Germanistik, (München: Hanser, 1972).

59 Reese 29. 
used in studying literature and focuses on the relationship between history and literature. Jauss's stated goal is to restore history to the center of literary studies, where a pervasive disregard for the historical nature of literature had evolved, as scholars had de-emphasized the historical nature of literature and became reoriented towards sociological, psychoanalytical, or aesthetic oriented methods. 60 Jauss advocates a reestablishment of the vital link connecting past works with present interests in order to rejuvenate the study of literature; this could only be achieved if literary history is raised to the forefront of literary study. In Jauss's initial lecture, "What is and for what purpose does one study literary history,"61 Jauss establishes a sense of urgency in a field that seemed stagnant and consequently in need of new orientation. "The rationale for a continued occupation with literature

60Holub, "introduction" 54 .

61Lecture delivered in April, 1967 at the University of Constance. 
[which] is lacking, especially in view of the demise of older models of interpretation." 62

The revised version of his "What is and for what Purpose does one study Literary History" lecture, "Literary History as a Challenge to Literary Scholarship" describes the events that led to the current situation. In Jauss's view, this situation resulted from the inadequacies of older methods of literary historiography. For example, Georg Gottfried Gervinus's History of the Poetic National Literature of the Germans (1835-42), like most nineteenth century histories, was rooted in the author's sense of national identity based on the teleological model. The problem with this type of historiography, according to Jauss, was: "The historian was faced with the dilemma of either projecting a closure into some future time and reading events backwards from this hypothetical point, or considering the goal as already achieved, thereby implying that subsequent events

62 Holub, "introduction" 54. 
were either inconsequential or part of a general demise. " 63

Jauss identifies the main alternative to teleological historiography, which evolved within the historicism of the nineteenth century. The father of this school, Leopold van Ranke, advocated full objectivity and total relativity in the following statement: "But I maintain that each period is immediate vis-à-vis God, and that its value depends not at all on what followed from it, but rather on its own existence, its own self."64 But every era remains self-sufficient destroying the link between past and present, which Jauss adamantly supports. Consequently, literary methodologies of historiography adapted principles that complicated the writing of literary history. 65

According to Jauss, the turn toward positivism is the result of this crisis, that by using methodology from the

$$
\begin{aligned}
& \text { 63Holub, "introduction" } 55 . \\
& 64 \text { Holub, "introduction" } 55 . \\
& 65 \text { Holub, "introduction" } 56 .
\end{aligned}
$$


natural sciences, analyzes literary works as if they were the consequences of verifiable and measurable causes: "The application of the principle of pure causal explanation to the history of literature brought only externally determining factors to light, allowed source study to go to a extreme degree, and dissolved the specific character of the literary work into a collection of influences that could be increased at will."66

Geistesgeschichte, literally translated "history of the spirit", the reaction to positivism in Germany, was also unable to bridge the gap between literature and history. Jauss observed: "Geistesgeschichte took hold of literature, opposed the causal explanation of history with an aesthetics of irrational creation, and sought the coherence of literature in the recurrence of atemporal ideas and motifs." 67

66Jauss, "Literary History as a Challenge to Literary Theory,"8. qtd in Holub 55.

67Jauss, "Literary History as a Challenge to Literary Theory," 8. qtd in Holub 56. 
Jauss states there are two alternatives to circumvent the simple chronicle of dates and works: the first proposes organizing the literary canon around general tendencies, genres, and other such categories, thus enabling the subsumption of individual works chronologically under these headings. The other popular method deals with major authors in blocks; this type of literary history would frequently consist of abbreviated "life and works essays." Both are unsatisfactory: "The former most often winds up being a history of culture with literary examples, while the latter is really a collection of essays bound together by the coincidence of loose chronological ties to nationality."68

In addition, Jauss alleges that neither of these traditional attempts at literary history can address the question of "evolution" and, focused on objectivity, these methods practice an "aesthetic abstinence," avoiding questions of quality. 69 Jauss insists that an outline of

68Holub, "introduction" 56. 69 Reese 27. 
the developments of individual types of literature cannot be qualified as history. Traditional literary history tends to avoid judgments of quality and instead relies on a predetermined, sanctioned canon of high literature. "It is not only rare but almost forbidden that a literary historian should hold judgments of quality concerning the works of past ages. Rather he prefers to appeal to the ideal of objectivity of historiography, which only has to describe 'how it really was'."70 Jauss states, a canon can only be established when the "criteria of influence, reception and posthumous fame are taken into consideration in assessing the quality and rank of a work, otherwise the historian, bound by objectivity and attached to the sure canon of the 'masterpieces' remains in his historical distance one or two generations behind the latest developments in literature."71

Jauss solves the problem through the combination of the historicity of Marxism and the aesthetic perception of

$$
\begin{aligned}
& \text { 70Jauss, "challenge" } 5 . \\
& 71 \text { Jauss, "challenge" } 5 .
\end{aligned}
$$


formalism. Through their one-sidedness, the Marxist and formalist theories finally arrived at an aporia, the solution to which demanded that historical and aesthetic considerations be brought into a new relationship. ${ }^{72}$ By making reception primary, the historicity of a work becomes dependent on its reception. ${ }^{73}$ However, Jauss criticizes both theories for their shortcomings, including giving far to little attention to the reception and effect of interpretation. Marxism, according to Jauss, recognizes the historicity of literature, but is an outdated form of criticism that is identified with the positivist paradigm. Jauss criticizes the concept of "reflection" (widerspiegelung) that identifies literature as a reflection of social/material reality; "the material horizon of conditions and objective praxis of Marxist aesthetics closes itself off from the modern development of art and literature."74

\footnotetext{
72Jauss, "challenge" 10.

73 Nemec, Solms 157.

74 Jauss, "challenge" 11.
} 
The formalists are credited with introducing the concept of aesthetic perception into literary theory, but Jauss also identifies their inadequacies. Jauss states, in Formalist theory "the process of perception in art appears as an end in itself; the 'tangibility of form' and the 'discovery of the device' are the principal components of the theory."75

Jauss continues by acknowledging another contribution by the Formalist School as being the history evolution of literature. The formalist method offered a new historical understanding in the area of the origin, canonization and decay of literature, advocating a dynamic principle of literary evolution as opposed to the classical concept of tradition. 76 This development, according to Jauss, turned the principle of literary evolution against the organicteleological sense of the classical concept of evolution. Jauss suggests a synthesis:

If on the one hand, literary evolution can be comprehended within the historical change of systems,

75 Jauss, 'challenge" 12 .

76 Reese 32 . 
and on the other hand pragmatic history can be comprehended within the process-like linkage of social conditions, must it also then be possible to place the 'literary series' and the 'non-literary series' into a relationship that comprehends the relationship between literature and history without forcing literature at the expense of its character or art, into a mere function of copy or commentary?77

The answer is outlined in his seven theses in "Literary History as a Provocation of Literary Theory." The main emphasis lies in the reception of texts and the revitalization of literary history. In Jauss's first thesis he calls for the "grounding of traditional aesthetics of production and representation in an aesthetics of reception and influence."78 According to Jauss, reception is pivotal because the dialogue between text and reader comprises literary history. In Jauss's next three theses the focus is on Jauss's main concept, the "horizon of expectations." This term not only covers the literary experience of the reader but also his "experience of life."79 Jauss implies that one can

$$
\begin{aligned}
& \text { 77Jauss, "challenge" } 18 . \\
& \text { 78Jauss, "challenge" } 20 .
\end{aligned}
$$


describe the reception and impact of a literary work objectively at the time of its publication because readers share expectations that can be revealed empirically. Some of Jauss's expectations are contemporary ideas about genre, knowledge of literary conventions of familiar works, and the difference between poetic and practical language. 80

The reconstruction of the "horizon of expectations" makes it possible to understand the literary work in its historical development. The distance between the given horizon and the appearance of the new work constitute "aesthetic distance;" when a new work challenges the current horizon it results in a change of horizon, which has aesthetic value. When expectations are simply met then the work becomes "culinary art." 81 Here, Jauss uses the ideas of Russian formalism (which equated artistic value

\section{Jauss, "challenge" 24 . \\ 80Margot Zutshi, "Hans Robert Jauss's} Rezeptionsästhetik-Theory and Application" IN. Richard Sheppard ed. New Ways in Germanistik, (New York: Berg 1990) 98 .

${ }^{81}$ Nemec, Solms 160 . 
with literary value), but also by using the "wider horizon of experience of life," he hopes to overcome the limitations of their approach. 82 Jauss's goal is to reveal how the original reader understood the work, illustrating the "hermeneutic difference" between past and present understanding.

The final three theses look at what a history of literature based on reception theory would entail and accomplish. Thesis five is the fusion of the diachronic and synchronic methods of analysis used in linguistics. In the diachronic method Jauss adapts Formalist methodology, which saw the process of literary change in terms of a ceaseless struggle between the new and the old that takes place entirely within the literary series. 83 Jauss sees this process as more convoluted--in this process the passive reception of the reader and critic is translated into the author's active reception and production. A synchronic investigation would mean describing and classifying all literature published in a given year. This

82 zutshi 98. 
would reveal the prevailing systems of literary codes and conventions. The sixth thesis is the analysis of the effect literary works have on society, via aesthetic form. The following are summaries of Jauss's theses.

VI. The historicity of literature rests not on an organization of "literary facts" that is established post festum, but rather on the preceding experience of the literary work by its reader. 84

VII. The literary expectations of the reader must be objectifiably described, which Jauss adopts from the basic tenets of Formalist aesthetics. Empirical evidence for the reconstruction of the "horizon of expectations" can for example be in the form of open or concealed signs.

83Jauss, "challenge" 34.

${ }^{84}$ Reese 33. 
VIII. The artistic character of a work is described by the aesthetic distance between it and the horizon of expectation of the audience.

IX. The reconstruction of the horizon of expectations is founded on the principles of Hans Georg Gadamer's Wirkungsgeschichte in which the text answers questions in certain situations of mediation.

x. The active reception and new literary production of later authors can be understood in the background of the conception of literary evolution.

XI. The diachronic perspective of literary history could be expanded through synchronic cross section that also defines and describes the factual incongruities of published and read literature of a certain time period.

XII. The task of literary history is thus only completed when literary production is not only represented synchronically and diachronically in the 
succession of its systems, but also seen as "special

history" in its own unique relationship to general

history. 85

85 Jauss, "challenge" 39. 
CHAPTER IV

\section{METHODOLOGICAL DEVELOPMENT}

Chapter V looks at reception theory's reception of the "classics" and the process of canon formation. Through the course of these three essays, "Literary History as a Challenge to Literary Theory," "The Partiality of Reception Theory," and "Aesthetic Experience as Rejuvenation of the Past," Jauss goes from complete refutation of the classics to conditional acceptance and finally full acceptance. In Theses one and Three of "Literaturgeschichte als Provokation der Literaturwissenschaft." Jauss's major theoretical tools, the "horizon of expectations" and the "aesthetics of negativity," are discussed as the foundation of his theory. The evolution of Jauss's perception of the "classics" is revealed through theoretical changes in the essays, "The partiality of Reception Theory," 86 first

$86_{\text {Hans Robert Jauss, "Racines und Goethes }}$ 'Iphigenie'," Neue Hefte für Philosophie, 4 (1973) 389. 
published in 1973 and "Aesthetic Experience as

Rejuvenation of the Past." 87

In "Literary History as a Challenge to Literary

Theory," Jauss discusses the concept of a literary history based on aesthetics and the role of tradition and canon formation.

The merit of a literary history based on an aesthetics of reception will depend on the extent to which it can take an active part in the ongoing totalization of the past through aesthetic experience. This demands on one hand--in opposition to the objectivism of positivist literary history--a conscious attempt at the formation of a canon, which, on the other hand-in opposition to the classicism of the study of traditions--presupposes a critical revision if not destruction of the received literary canon. 88

In his first thesis Jauss attacks the concept of classicity within literary history by advocating a process that goes against the methodology of the "classics." Jauss begins by defining a literary work as an event in the

${ }^{87}$ Hans Robert Jauss, "Ästhetische Erfahrung als Verjüngerung des Vergangenen," Sprache und Welterfahrung, ed Jörg Zimmerman (München: Fink, 1978) 301-328.

$$
88 \text { Jauss, "challenge" } 20 .
$$


development of the historical category. Literary history is a system of aesthetic reception and production on the part of the reader, the critic and the author in continuing productivity. 89 Jauss states that literary work is not some autonomous object that offers the same view to each reader in each period, but "the meaning of a text is defined as a convergence of the structure of the work and the structure of the interpretation which is ever to be achieved anew."90 The fate of a literary work is determined by its reception over time, and it can continue to have an effect only if succeeding readers and authors still or once again respond to it; if there are readers who again appropriate the past work or authors who want to imitate or refute it.

Jauss's main theoretical concept (responsible for the integration of Marxism and Formalism), and the foundation of his assault on the classics, is the "horizon of expectations"(Erwartungshorizont). The "horizon of

$$
\begin{aligned}
& 89 \text { Jauss, "challenge" } 21 . \\
& 90 \text { Segers "interview" } 84 .
\end{aligned}
$$


expectations" is the combination of responses, prejudgements, verbal and other behavior that a work originally encounters.91 A work satisfies a "horizon" by substantiating the expectations of the recipients, or it may fail to confirm expectations by leaving a distance between itself and expectations, which Jauss calls "aesthetic distance". "Aesthetic distance" is a pivotal factor in constructing literary history, since it leads to one of two main processions: "Either the public changes its "horizon", giving acceptance to the work, establishing a stage in the aesthetics of reception, or a work is rejected, and it may then lie dormant until accepted."92 According to Jauss, the historical factor is reintroduced as the recipients of the text present and past, are engaged as text mediators. The public also mediates between old and new works supplying the foundation for the understanding of the literary sequence, which historiography will record. 93

$$
\begin{aligned}
& \text { 91Jauss, "challenge" } 24 . \\
& \text { 92 Jauss, "challenge" } 25 .
\end{aligned}
$$


In Jauss's third thesis the "horizon of expectations" is used again to refute classicism. The method for assessing literary value which uses "aesthetic distance" attempts to determine whether a work has disappointed, exceeded, or destroyed expectations. Jauss states, "The degree to which "aesthetic distance," the distance between the "horizon of expectations" and the work, to the degree that this distance decreases, and no turn in the direction of horizon of unknown experience is demanded of the reader, the closer the work comes to the sphere of entertainment art."94 The objectification of this "horizon" through Jauss's previously discussed methodology, provides the foundation for determining the distance between the expectations and the work. Jauss highlights works that either parody the literary tradition or reflect it such as Don Quixote and Chimeras. These works are optimal examples because they "evoke the reader's horizon of expectations, formed by a convention

$$
\begin{aligned}
& 93 \text { Jauss, "challenge" } 25 . \\
& 94 \text { Jauss, "challenge" } 25 .
\end{aligned}
$$


of genre, style, or form only in order to destroy it step by step." 95

Jauss uses Adorno's "aesthetics of negativity" and the Formalist's theory of perception through defamiliarization [ostrenenie] in establishing value. The "aesthetics of negativity" refers to literature that doesn't conform to the readers "horizon of expectations"(i.e avant-garde art). Jauss considers only avant-garde literature significant, because it doesn't confirm the readers "horizon of expectations." Thus "classics" based on canonical tradition are questioned:

Their beautiful form that has become self evident, and their seemingly unquestionable 'eternal meaning' bring them, according to the "aesthetics of reception", dangerously close to the irresistibly convincing and enjoyable 'culinary art', so that it requires a special effort to read them "against the grain" of the accustomed experience to catch sight of their artistic character once again. 96

95Holub, "introduction" 60.

96Jauss, "challenge" 26. 
Consequently, the historian of literary reception is repeatedly asked to reevaluate the canon and to determine how they have affected and are affected by current events.

In Jauss's essay "The partiality of reception theory" published first in 1973, under the heading "Tradition and selection," Jauss has changed his stance regarding the classics. Jauss no longer refutes canon formation through tradition; he now reveals a dichotomy of "chosen" and "grown" tradition. Tradition is not simply passed down by itself. "Chosen tradition" is a conscious subjectivity of selection and rejection that represents a new reception of past works such as the classics that are to always be interpreted anew.97 In "grown tradition," according to Jauss, works of art become accepted through a consensus of literary society or in academic canons as their literary codes and conventions become tradition through preconceived expectations of later generations. This occurs, as the work of art sheds its individual

97Irmgard Wagner, "Hans Robert Jauss and Classicity" MLN Dec v99(5) (1984) 1176. 
characteristics, thus reduced to a style direction resulting in "grown tradition". However, "chosen tradition" can also lead to the breakdown of "grown tradition" by discarding the previous tradition of literary criticism and reevaluating the canonical past thus leading to a redemption of forgotten heritages. According to Jauss, redemption of the classics occurs through his new concept "actualization," defined as the re-cognition(Aufarbeitung) of the historical process that extends between the past work and it's present recipient. 98

In the essay "Aesthetic Experience as Rejuvenation of the Past," published in 1976, Jauss again has altered his theoretical position, as he has gone from rejection to critical conditional acceptance and finally to a new acceptance. Jauss's position continues to move away from the "aesthetics of negativity," which played a central role in "Literary History as a Challenge to Literary Theory." The focus is no longer the negation of

$$
98 \text { Jauss, "Racines" } 389 .
$$


classicity; the new perception alters the past, thus preserving it in the present: "The aesthetic experience in the process of canon formation gives each work of art not only a new meaning as well as opening up a new world, but also shows the past work in a new light. It is also characteristic in the "aesthetic experience" of canon formation that the innovation of the past is not simply discarded, but changes along with 'aesthetic experience'."99 According to Jauss it is no longer a question of whether or not to accept the classics, it is a conceptual matter of how the classics are to be accepted and interpreted in the present. This point is further reinforced by Jauss's positive terminology in reference to canon formation: "canon formation is a process of transformation, appropriation, selection and rejuvenation" [Umbildung, Aneigung, Auswah], Verjüngerung].100 Jauss addresses the nature of how past works are isolated from present works and how secluded past works

99Hans Robert Jauss, Ästhetische Erfahrung und literarische Hermeneutik I (München: Fink, 1977) 303. 100 Jauss, Ästhetische 308. 
are once again revived through an analysis of the historicity of language and literature. Jauss states, "the evolution of language is based on the overcoming of previous language through revision or adoption. New norms form within this process, since the transformation of language constantly discards language elements and leaves them behind in the foreignness of past language."101 Language usage slowly moves into the past and ends up a dead language that is sometimes quoted but never fully actualized. According to Jauss, the evolution of language and "aesthetic experience" have in common the dynamic character of open systems, which must constantly be transferred in order to function. But "aesthetic experience," in addition, brings new meaning, opening up potential new worlds and showing past works in a new light, in the advanced standardization and traditionalization of art.102

101Jauss, Ästhetische 303 . 102 Jauss, Ästhetische 303 . 
For Jauss it is now a question of how classics are accepted and interpreted: "This everlasting tradition is subject to a process of constant canon construction, and reconstruction, appropriation, selection and rejuvenation."103 The building of tradition appeared from the beginning of the history of European art as a process of mediation between past and present experience as a never ending Querelle des Anciens et des Modernes. The main goal in "Aesthetic Experience as Rejuvenation of the Past," is the refutation of a timeless and ever-present classic and the acknowledgment that the classics must always be perceived anew, in order to open them up again to aesthetic enjoyment.104

The previously discussed evolution of Jauss's theory reveals that "Literary History as a Provocation to Literary Theory" marked a theoretical turning point for Jauss. Jauss retained his interest in investigating the interaction between audience and text and his concern for

103 Jauss, Ästhetische 308 .

104 Wagner 1178. 
literary history. However, in the 1970s the role of the Russian formalists diminished as their views of defamiliarization, similar to Adorno's "aesthetics of negativity," the concept of an evolutionary literary history, and Jauss's previous main theoretical concept, the "horizon of expectations" was for the most part eliminated.105

A main reason for the refutation of major concepts in Jauss's earlier work is possibly connected to Jauss's devaluation of Theodor Adorno's "aesthetics of negativity," that was discussed in Adorno's Aesthetic Theory in 1970. The problem with Adorno's theory is that it allows a positive social function for art only when it goes against the conventional societal practices that it comes from, which was the foundation for the refutation of the classics.106 Consequently, there was no place for an affirmative and progressive literature since literature is defined by its opposition to social practices.

105Wagner 1181.

106 Holub, Introduction 63. 
Jauss also de-emphasized his major concept, the "horizon of expectations," due to difficulties in implementation. In Jauss's essay's the word appeared in a multitude of compound words and phrases; Jauss mentions a "horizon of experience," a "horizon of experience of life," as well as "horizontal change," and they are all vaguely defined. Jauss seems to refer to the "horizon" as some sort of structure of expectations a person brings to the interpretation of the text. This does not alleviate difficulty in usage. For example, Jauss refers to the "objectification" of the "horizon of expectations" through reconstructing familiar norms of a genre, familiar works of the literary--historical surrounding or through identification of the opposition between poetic and practical language.107 The problem lies in Jauss's assumption of an empirically objectifiable procedure for the horizon that presupposes a neutral position from which these observations can be made. The familiar standards for a given era are verifiable only by assuming that from a present perspective we can make objective judgments of 
what these standards really were.108 Thus we are asked to ignore our own historical situation which brings Jauss back to the historical-positivist paradigm he attempted to escape from.109

107Jauss, "challenge" 24.

108Holub, Introduction 62 .

109 Holub, Introduction 63. 
CHAPTER V

EMPIRICAL STUDIES

In the course of debate which followed Jauss's essay "Literary History as a Challenge to Literary Theory", criticism focused on Jauss's concept of an objectively achievable "horizon of expectations": objections were that it was impossible to portray the past objectively or to objectively determine the "wider horizon of expectations of life". How was one to objectively document the influence of social, political and economic factors and their impact on reader expectations? The second target of critics was the lack of distinction in Jauss's definition of his reader. Criticism also addressed Jauss's disregard of social and psychological influences that led to a limited view of the reading experience. "He(Jauss) adheres to a concept of audience that fails to differentiate according to social standing, education, sex and reading preferences--to name but a few variables."110 The 
following empirical studies will address some of the critical debate involving reception theory including: the attempt to apply an objective "horizon of expectations" and "wider horizon of experience of life;" the psychological perspective of the reader; and the effect of the social environment in reception. The empirical study by Eggert, Rutschky, and Berg looks at the psychological aspect by analyzing the effect of the method of discourse and the social context on the students' interpretations. Hillman's study focuses on students' interpretations of a text(author not identified) and draws conclusions about the effect that the social background and standing of the students have on their choice of methods, conventions, and associations used in interpreting the text. Vaget's study attempts to test the objectivity of Jauss's "horizon of expectations" and the wider "horizon of expectations of life," questioning the applicability of one of Jauss's major concepts.

110Henry J. Schmidt, "Text-Adequate Concretisations" and Real Readers: Reception Theory and its Application," New German Critique, 17, (1979) 158-59. 
EGGERT, RUTSCHKY AND BERG'S STUDY

The first study is an interdisciplinary work conducted by Berg, Rutschky and Eggert combining the fields of psychology, sociology and literary theory in analyzing the study of literary criticism in German schools. In this study, tenth and twelfth grade students interpreted texts of Brecht, Kafka, Benjamin, and Kleist. The study immediately identifies the importance of psychological and social factors in reception that Jauss for the most part neglected. According to Eggert, Rutschky and Berg, reception is not portrayed in its natural state: "The interpretation formed in the head of the reader during the lecture cannot be deciphered unaffected by the interviewer; on the contrary, the reception is much more the result of an interaction, in which the interviewer has given the students a task to formulate his or her interpretation. The text is socially conditioned from the beginning."111 According to this study the social context 
cannot be overlooked in analyzing the reception of texts. Readings, remarks, and interpretation of the material are tasks that the interviewer gives to the students; the interviewer represents the text and a claim of its understanding and expects an explanation, therefore, "the text is tied to the role of the interviewer or a third person against whose approval or disapproval understanding will be judged. In addition, the text takes on certain characteristics of a school assignment, which hinders understanding, through added pressure."112

Eggert, Rutschky and Berg identify the interaction between text and reader as a microcosm of communication. "The text takes on certain characteristics in different social contexts that structure the task of comprehension. The question thus remains how the reader expresses the recognition of these characteristics in different social

111Hartmut Eggert, Hans Christoph Berg, Michael Rutschky, "Zur notwendigen Revisions des Rezeptionsbegriffs," IN. Historizität in sprach und Literaturwissenschaft: Vorträge und Berichte der Stuttgarter Germanistentagung, (München: Fink, 1974) 425 .

112Eggert, Berg, Rutschky, 427. 
contexts."113 Analyzed within this social context the psychological processes that occur in the students are increased or suppressed by the demands of the interviewer. The students applied formal recording operations: they read the text multiple times; identified and questioned unclear sections; and noted unique linguistic and stylistic examples. Above all they concentrate on key theoretical terms about the text (for example perception vs. reality for both paragraphs on Kafka's parables) and attempt to summarize the text through these devices.114 Eggert, Rutschky and Berg conclude that the responses must be integrated into the entire realm of cognition, effects, perceptions, motives, interests and norms. They advise caution in reconstructing these interpretations because of the many factors involved "The the claims, responses, or interpretations that are given and which relevance the students give them; and the decision whether or not to articulate a certain thought or association in a

113 Eggert, Berg, Rutschky, 428 . 114 Eggert, Berg, Rutschky, 428 . 
specific context; both directly affect the responses of the students."115

\section{HILLMAN'S STUDY}

Hillmann's study discusses the interpretations of vocational school students and college students who were asked to write a response to the three Kafka lines in "Das Wiedersehen" (without naming the author): "Ein Man der Herr $\mathrm{K}$ lange nicht mehr gesehen hatte, begrüsste ihn mit den worten: Sie haben sich gar nicht verändert" 'Oh', sagte Herr $\mathrm{K}$ und erbleichte."116 The study investigates associations documented by concrete answers and their visible tendencies. According to Hillman, the results reveal that in a unconventional study such as this, where the students often don't know the name of the author, actualizations are much more dependent on social groups

115Eggert, Berg, Rutschky, 431.

116 Heinz Hillman, "Rezeption-Empirisch," IN Walter Müller Seidel ed., Historizität in Sprach-und Literaturwissenschaft, (München: Fink, 1974) 440 . 
and education systems.117 Again an objective approach of documenting the readers interpretation is questioned using Jauss's model. The social context is relevant to the interpretation, thus the "wider horizon of expectations of life" would be useful, but was never fully developed by Jauss.

Hillman's method attempts to schematize and quantify responses using motives of interpretations which concentrate on certain parts of the text. Through this schema conclusions are reached in relation to the different groups.

The categories are the following:

A. Establishment of a conventional idiom and statement

1 agreement

2 criticism

3 dismissing premature judgments and unreliable conclusions of oneself 
B. Establishment of the means of identification of actual or desired change for $\mathrm{Mr} . \mathrm{H}$

1 appearance

2 social mobility

3 moral evaluation

4 personal development

5 increased knowledge, new experiences, self reflection

C. Abnormal behavior or criminal past - personal development or regression towards past negative behavior

1 outlining a criminal

2 guilt about criminal past - suppression of improvement

Hillman cites examples from the study: A female vocational school student relates the text to her personal experience, identifying a important social context and the feelings and values tied to it (social recognition). She 
equates this with a rise in social status that she highly values: "Perhaps it can be compared to two women meeting; one is attractively made up and wearing a new dress. If someone would say to her: you haven't changed at all, she would possibly become pale and angry."118

A second example of a vocational school student: "I understand the blushing. Who would like to hear that they haven't developed? I would be the same way as Herr $\mathrm{K}$. For example, when I visit relatives, they respond similar to the man. This is wrong, as I believe that I am constantly developing just like every other man does or should do. Even when he is only referring to the other man's external appearance it is not appropriate." . Above all as a child, who constantly hears: you have not changed at all, one is not exactly excited, one wants to feel grown up. The man spoke casually and is not aware of his words." Conversely, A gymnasium student: "A third possibility is that Herr $\mathrm{K}$ (as this work is from Brecht) was a National Socialist in the war and is not completely 
innocent in the deaths of many people. The man could possibly be one of his victims, who now reluctantly greets him--Herr $\mathrm{K}$ reacts afraid and guilty."119 The Gymnasium student sacrifices an interpretation based on her personal experience for a literary association to the author, in this case Brecht, possibly based on one of his previous works: Furcht und Elend des dritten Reiches, Massnahme gegen die Gewalt.

A second example cited by Hillman of a Gymnasium student: "Starting point: because this is a short story from Brecht one should immediately identify a social or societal criticism."120 Empty spaces are filled in, in reference to the entire work not from one's personal life, as a result of the conditioned educational conventions. Hillman found that a conflict of interest arises when an analogy or parallel to one's own life is used; this leads to a inner conflict as the students understand the

$119 \mathrm{Hillman} 445$.

$120 \mathrm{Hillman} 442-43$. 
text and can relate to it, but they don't think they understand the intended "meaning."121

Hillman concludes: "the uninhibited vocational school students relate the text to their personal life constantly saying "I"; the Gymnasium students have inhibited responses and relate the text to prejudices in regard to society, literature and the author, constructed in the passive always referring to "one."122 The students preparing for college at the Gymnasiums are conditioned to apply specific methodologies in this situation due to social conditioning.

VAGET'S STUDY

Hans Rudolph Vaget applies the "horizon of expectations" to the reception of Thomas Mann's Buddenbrooks. Vaget has subdivided the "horizon of

$121_{\mathrm{Hill}} \mathrm{man} 444$. $122_{\mathrm{Hill}} \mathrm{man} 445$. 
expectations" into four categories, author expectations, literary work expectations, literary expectations and epoch expectations. The expectations based on the literary work did not exist because this was essentially a debut for Mann. The expectations of the author are also discounted since Mann was basically an unknown at the time. The literary expectations based on prevailing codes and conventions were, according to Vaget, the most informative category in regards to the study: in a long list of reviews and articles the length and composition of the Buddenbrooks was encountered with skepticism, revealing distance between the work and the prevailing expectations. "The extensive use of the leitmotif gave rise to skepticism and negative comments indicating that these formal innovations represented a challenge to the conventions of the social novel."123 The epochal expectations revealed similar results as decadence was for the first time being discussed in the upper middle class and provoked criticisms in some review articles. This is 
contrasted against Gustaf Freytag's Soll and Haben in which decadence and pessimism had been portrayed as solid pillars of society. Vaget summarizes that on one side the narrative strategies of the novel broke tradition, but on the other hand in regards to genre the novel was praised for its realism, authenticity and accuracy, thus being perceived as "norm-fulfilling."124

Vaget suggests that further aspects of the earlier novel could be revealed through study of its reception, but still chooses to focus on the methodological side. Vaget states that all articles and reviews were treated equally and "as if they were situated in a social and ideological no-man's-land,"125 and argues that it is then necessary to identify in what way historical and social factors played a role, i.e. to recreate the readers' "wider horizon of experience of life."126 Despite Jauss's

124 Hans Rudolph Vaget, "Rezeptionsästhetic: Schwerigkeiten mit den Erwartungshorizonten am Beispeil des Buddenbrooks," Monatshefte, 71 (1979) 406.

125 Vaget 406 .

126 zutshi 103. 
intentions, theoretical gaps and conceptual weaknesses exist, as the historical and societal determinants used to outline the "wider horizon of experience of life" are not provided. Consequently, according to Vaget, reception theory has failed to identify the relationship between literary reception and societal behavior that would only be possible with an empirical "horizon of expectations" and reception. Vaget concludes, "the real Buddenbrooks reader of 1901, like the reader who was involved in later stages of the novel's reception, remains a phantom, and moreover, that it would be mere speculation to draw conclusions about socially formative effects from the extremely limited evidence available."127 
CHAPTER VI

CONCLUSION

This study discussed the theory and application of Hans Robert Jauss's reception theory and used the sociology of knowledge approach to analyze the social and political environment that constitute the backdrop for the introduction of reception theory. In addition the relationship between institutional reforms at the University of Constance and Jauss's methodology are explored, revealing the influence of institutional reforms on the positive reception of reception theory.

Chapter one began by outlining the intellectual

movements that contributed to the development of reception theory: Russian Formalism, Prague Structuralism and the hermeneutics of Hans Georg Gadamer: Russian formalism and Prague structuralism provided the theoretical framework for the shift in emphasis from the autonomous text to the reader by concentrating on aesthetic perception. In addition they contributed in the area of an evolutionary, 
literary history adopted by Jauss's reception theory. Gadamer's most well known work Truth and Method provided fertile ground for reception theory as Jauss used many of Gadamer's concepts in his major essays. Chapter Two illustrated the institutional reforms brought about by Jauss and his colleagues at the University of Constance. Jauss was active in reforming the language and literature departments by convincing once alienated faculties to devote their energies to a new cooperative, interdisciplinary program of literary studies under the title Literaturwissenschaft. Chapter Three discussed Jauss's main concepts and ideas on literary history and its evolution introduced in the essays, "Paradigmawechsel in der Literaturwissenschaft" and "Literaturgeschichte als Provokation der Literaturwissenschaft." Chapter Four outlined Jauss's reception theory in regards to the classical genre and chronicles its development from complete refutation of the classics to total acceptance. Chapter Five looked at empirical studies that challenged the major ideas of Jauss's reception theory. 
The institutional reforms at the University of Constance created an ideal platform for the introduction of Jauss's reception theory. Through the democratization of institutions and the revision of scholarly practices, autonomous departments were broken down and replaced with subject areas that worked in an interdisciplinary and cooperative manner and were open to the idea of new theoretical understanding. In the department of Literaturwissenschaft, the established canon was questioned along with its methodologies, and a criticism was sought that could account for contemporary literary works as well as the classics. This resulted in a positive reception of Jauss's theory within German literary criticism and other social science disciplines where reception theory dominated for the next decade.

Jauss's version of reception theory emphasized the reader's reception of a text at a specific time or over a specific time period and the development of the reader's reception. By focusing on an evolutionary literary history, Jauss declared prevailing modes of criticism 
outdated and asserted that they could no longer adequately fulfill their obligations in dealing with contemporary literary issues. Jauss's reception theory called for the advancement of new theories and the destruction of the literary canon; this offered the student movement exactly what they wanted. The study concludes that the democratic reforms at the University of Constance provided the ideal environment for the introduction of Jauss's theory, and opened the door for the advancement of theory and criticism that could deal with contemporary literature. 
REFERENCES

Aesthetic Experience and Literary Hermeneutics, trans. Michael Shaw Minneapolis: University of Minnesota Press, 1980.

Eggert, Hartmut, and Hans Christoph, Berg, and Michael, Rutschky. 1972: "Zur notwendigen Revisions des Rezeptionsbegriffs", in: Historizität in Sprach und Literaturwissenschaft, Vorträge und Berichte der Stuttgarter Germanistentagung 1972, Walter MüllerSeidel. München: 1974, 423-432.

Gadamer, Hans Georg. Wahrheit und Methode, Tübingen: Mohr, 1972 .

Hillman, Heinz. "Rezeption-Empirisch," Ed. Walter Müller Seidel. Historizität in Sprach-und Literaturwissenschaft, München: Fink, 1974: 433-449.

Holub, Robert C. Reception Theory: A Critical Introduction. New York: Metheun, 1984.

Holub, Robert C. "Trends in Literary Theory: The American Reception of Reception Theory," The German Ouarterly. $198255,80-96$.

Iggers, Georg G. The German conception of History: The National Tradition of Historical Thought from Herder to the Present. Middletown, Conn: Wesleyan University Press; Scranton PA: Harper @ Row, 1983. 
Jameson, Fredric. The Prison House of Language: A Critical account of structuralism and Russian Formalism. Princeton: Princeton University Press, 1972.

Jauss, Hans Robert. "Paradigmawechsel in der Literaturwissenschaft," Linguistische Berichte. 1969 $3,44-56$.

Jauss, Hans Robert. Literaturgeschichte als Provokation der Literaturwissenschaft. Frankfurt: Suhrkamp, 1970.

Jauss, Hans Robert. "Racines und Goethes Iphigenie: Mit einem Nachwort uber die Partialität der rezeptionästhetischen Methode," Neue Hefte für Rhilisophie. 1973 4, 1-46.

Jauss, Hans Robert. Ästhetische Erfahrung und Literarische Hermeneutik I. München: Fink, 1977.

Jauss, Hans Robert, and Nesselhauf, Hermann. Gebremste Reform. Ein Kapitel deutscher Hochschulgeschichte, Universität Konstanz 1266-76. Konstanz: Universitätsverlag, 1977.

Jauss, Hans Robert. "Literary History as a Challenge to Literary Theory," Ed. Towards an Aesthetics of Reception, trans. Timothy Bahti. Minneapolis: University of Minnesota Press, 1982.

Kolbe, Jürgen. Neve Ansichten einer künftigen Germanistik, München: Hanser, 1973.

Kosik, Karel. Die Dialektik des Konkreten, Frankfurt: Suhrkamp, 1967. 
Mukarovsky, Jan. Aesthetic Function, Norm and Value as

Social Facts, trans. Mark E. Suino Ann Arbor:

University of Michigan Press, 1970.

Philisophical Hermeneutics, trans and ed. David E. Linge, Berkeley: University of California Press, 1976.

Reese, Walter. Literarische Rezeption, Stuttgart: Metzler, 1980.

Segers, Rien T. "An Interview with Hans Robert Jauss," New Literary History 197911 no 1, 83-95.

The Word and the Verbal Act: Selected Essays by Jan Mukarovsky and structure, Sign and Function, edited and trans. John Burbank and Peter Steiner, New Haven and London: Yale University Press, 1977.

Tomashevskii, Boris. "Literature and Biography," 1971: 4755. Ed. Ladislav Matejka and Krystyna Pomorska. Readings in Russian Poetics, Cambridge, Mass: MIT Press.

Wagner, Irmgard. "Hans Robert Jauss and Classicity," MLN. 1984 Dec v99(5), 1173-1184.

Zutshi, Margot. "Hans Robert Jauss's Rezeptionsästhetik: Theory and Application," Ed. Richard Sheppard. New Ways in Germanistik, New York: Berg, 1990, 95-111. 